\title{
BIHAR MEGYEI IDEGENFORGALMI SZOLGÁLTATÓK SZERKEZETI JELLEMZŐI, A VÁLLALKOZÁSOK TÉRBELI VETÜLETEI
}

\author{
Czuczor Krisztina
}

\section{Összefoglalás}

Bihar megye turisz̨tikai tökéje összetett, több turizmusra irányuló fejlesztés is megvalósult az utóbbi években, ugyanakkor a frissen megjelent kutatások nem foglalkoznak azon vállalati sz̧éra gazdasági-társadalmi súlyával, mely a

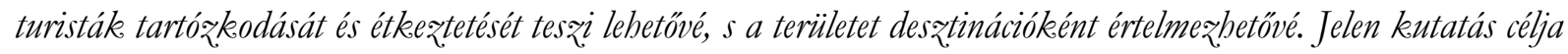
a Bihar megyében aktivan müködö szálláshely-szolgáltató és vendéglátó egységek területi szerkezeti feltárása, mely keretén belül a tevékenységi területük, az árbevétel és azéves átlag alk.almazotti létszám alapján vizsgáltam azokat, a 2005-2020-as idöszakban. A sqakirodalmi kutatást követöen egy megyei vállalati leltárt készítettem külön kezzelve a két vállalati csoportot, azok tevékenységi alágazatai szerint, melybe a megye összes, 2021. június 15-ig müködō szálláshely-, illetve étkez̨etetési-és italszolgálást nyújtó vállalata került be. Ez̨t követöen Bihar megye településeit potenciális desztinációtipusokba soroltam adottságaik és elhelyezkeedésük alapján, majd megvizsgáltam önkormányzati és desz̨ináció típus sqintjén a vállalkozások tevékenységi köreik szerinti, illetve árbevételeik és átlag éves alkalmąotti létszámuk szerinti megoszlását. A kutatának megfelelóen az idóborizont két kritikus esemény, a gazdasági válság és a pandémia hatásainak területi-gazdasági vizsgálatát is lehetövé teszi. Utóbbi, a vizsgált mutatók tanúsága szerint, erösebben sújtotta a vállalatokat. Elmondható, hogy nagy területi különbségek vannak. jelen Bihar megyében a két vállalati csoport vizsgált adatainak megfelelöen, mely szerint önkormányzati szinten, desztinációtipus szintjén és megyei átlagban mérve eltérö tendenciák érvényesültek, ami a terület sikerességére is utal, mint desżtináció. Az eredményeket önkormányzati bontásban kartográfiai módszerek által szemléltetem.

Kulcsszavak: turizmus, Bihar megye, szállás- és vendéglátóbelyek, területi megoszlás, vállalati hálózat JEL: Z29

\section{STRUCTURAL CHARACTERISTICS OF TOURISM SERVICE PROVIDERS IN BIHAR COUNTY, SPATIAL DIMENSIONS OF ENTERPRISES}

\begin{abstract}
Bihor County has a complex tourism capital, numerous tourism development activities have been implemented recently, although the latest researches do not involve the socio-economic weight of that business sector which enables the overnight stay or consumption by tourists, also the classification of the area as a destination. The aim of the present research is to explore the territorial structure of currently functioning hospitality service providers, therefore I examined them on the basis of their field of activity, sales revenue and the annual average number of employees within the period 2005-2020. Following the literature research, I generated two separate inventories of accommodation providers and hospitality unites for Bihor County according to their activity fields, which contain all still functioning companies
\end{abstract}


until $15^{\text {th }}$ of June, 2021. Subsequently, I classified the territories of local governments of Bihor County into potential destination types based on their characteristics and location, and then examined the distribution of companies according their abovementioned data. According to this research, the time horizon also allows the spatial-economic analysis of the effects of two critical events, the economic crisis and the pandemic. The latter, according to the examined indicators, brought a greater negative impact on the businesses. In conclusion, there are large territorial differences in Bihor County according to the data of the two groups of companies, although distinct trends characterized the local, destination type and county levels which could refer to the successfulness of an area as a tourist destination. I illustrate the results by cartographic methods, in the breakdown of local administrative units.

Keywords: tourism, Bibor county, accomodation and food and beverage suppliers, territorial distribution, network of companies

JEL:Z29

\section{Bevezetés}

Bihar megye fejlődő idegenforgalmának térbelisége nagymértékben az itt működő szállás- és vendéglátói szolgáltatást nyújtó vállalatok szerkezetét vizsgálva tárható fel. Egyrészt földrajzi elhelyezkedésük meghatározza a turisztikai erőforrások hasznosítási lehetôségeit abból a szempontból, hogy egyáltalán beszélhetünk-e desztinációként az adott területről, az alapvető feltételek megteremtése által. Másrészt a szolgáltatók jövedelem- és munkahelyteremtő képessége kiemelt szerepet képviselhet olyan térségekben, ahol más típusú gazdasági tevékenységek egyáltalán nem vagy korlátozottan mûvelhetôk.

A szolgáltatás-kínálat diverzifikáltságának mértéke a turisták igényeinek magasabb szintű kielégítéséhez vezethet, ezért e felmérés a területi potenciál mérlegelése mellett befektetési lehetőségeket tárhat fel a köz-, illetve magán szféra érdekeltjei számára egyaránt.

\section{Az idegenforgalmi elsödleges szuprastruktúra jelentôsége}

Az infrastruktúra fontos tényezője az életminőségnek, mely tulajdonképpen olyan technikai ellátottságot jelent, ami a termelés, szolgáltatás és lakás funkció problémamentes múködését és a társadalom életkörülményeit fejleszti. Az általánosan értelmezett infrastruktúra a vonalas hálózatokat, a közmûveket, illetve a közlekedési rendszereket foglalja magába, valamint szélesebb értelmezésében a védműveket, az egészségügyi ellátórendszerek intézményeit, a közbiztonságért felelős szerveket, tűzoltóságot és köztisztaságért felelős vállalatokat is. (Michalkó, 2007a) Turisztikai szempontból az elérhetőség, megközelíthetôség és a környezeti alapfeltételek meglétét biztosítja (Bujdosó, 2016).

A turisztikai alapinfrastruktúrában az idegenforgalom olyan tárgyi feltételei épülnek egymásra, melyek lehetővé teszik a vonzerôk feltárását, értékesítését és piacképességét. A turisztikai infrastruktúra által válnak az attrakciók hasznosítható, a turisták által fogyasztható elemekké. (Michalkó, 2007a) A szakirodalom egy része a profitorientáltan múködő turisztikai fogadóstruktúrákat és létesítményeket is a turisztikai infrastruktúra fogalma alatt értelmezi tágabb értelmezésben tekintve arra (Lengyel, 2004; Dwyer-Forsyth-Dwyer, 2020 stb.), míg mások különválasztják az idegenforgalmi 
infra- és szuprastruktúra fogalmát (Lickorish-Jenkins, 1997; Tasnádi, 2002; Michalkó, 2007a, b; Irimiás-Jászberényi-Michalkó, 2019; Cooper, 2021 stb). Mindazonáltal Lengyel Márton (2004) kiemeli azt a tényt, hogy a turizmus általában a lakossági infrastruktúrát veszi igénybe és arra épül ki, mivel kifejezetten az idegenforgalom gyakorlásának céljából igen ritkán építenek ki hálózati infrastruktúrát, viszont hiányában igen nehéz a turizmust fejleszteni.

A szálláshelyek azért tartoznak a szuprastruktúra (felépítmény) elemei közzé és nem a szűkebb értelemben vett infrastruktúra (alépítmény) részét képezik, mert elsődlegesen vonzerôvé kell fejleszteni az idegenforgalmi erőforrásokat (Dávid-Jancsik-Rátz, 2007; Horváth, 2013), előbb a keresleti igényeket kell előmozdítani a térség iránt, majd ennek következtében a jelen levő keresleti igényekre, valamint a már kialakított infrastruktúrára épülhet rá a szálláshely- és vendéglátó szektor (Horváth, 2013). Tulajdonképpen az infrastruktúra a szuprastruktúra kialakításának alapfeltételét képezi bizonyos szinten. Például, ha egyáltalán nem, vagy csak nehezen közelíthető meg egy attrakció, akkor a látogatók száma is alacsony lesz, illetve a meglétéről sem szereznek tudomást, melyből kifolyólag a szálláshely-kereslet sem alakul ki.

- A turizmus tárgyi feltételei a következő sorrendben épülnek egymásra (Michalkó, 2007a):

- A vonzerő helyezkedik el a középpontban, amely értékesítése nem valósulhat meg a további, ráépülő tényezők nélkül

- Az idegenforgalmi infrastruktúra, mely nem feltétlenül csak a turisztikai folyamatok zavartalan lebonyolításához járulnak hozzá, hanem a lakosság életkörülményeit is javítják (közlekedés, közmûvek és kommunikáció)

- Az elsődleges szuprastruktúra, mint a szálláshelyek és vendéglátó-egységek

- Másodlagos szuprastruktúra, mint a kiskereskedelmi, személyes- és egyéb kiegészítő szolgáltatások

Az idegenforgalmi szuprastruktúra fogalmát Claude Kaspar svájci kutató vezette be a turizmuselmélet fogalomkörébe, mely a vendégek tartózkodását és fogyasztását teszi lehetôvé. A turisztikai szuprastruktúra az adott célterület szálláshely és vendéglátó-ipari kínálatát, valamint az attrakció feltárásán és értékesítésén kívüli szolgáltatások teljességét foglalja magába. A bevételek fốbb része ebben a szegmensben képződik, ezért kiemelt szerepet képvisel a gazdaság szemszögéből. (Michalkó, 2007a) A szálláshely és vendéglátó szolgáltatások tárgyi feltételei egy desztináció fogadóképességének, melyet az elsődleges jelző által különböztetünk meg a kínálatot nagyrészt mindössze kiegészítő szolgáltatásoktól (Michalkó, 2007b).

$\mathrm{Az}$ elsődleges szuprastruktúra hiányában bonyolult lehet egy térség idegenforgalmi desztinációként való értelmezése, mivel a vendégforgalom megfelelő lebonyolításának olyan elválaszthatatlan attribútumai, amelyek legtöbbször közeli szimbiózist formálnak egymással és a turisztikai infrastruktúrával egyaránt. (Michalkó, 2007a)

A másodlagos szuprastruktúra egy idegenforgalmi desztináción jelen levő olyan szolgáltatások együttese, amelyeket a vendégek a kiskereskedelmi ellátásban, az egyéni szükségleteik kielégítésében vagy a helyi, illetve térségi mobilitás érdekében vesznek igénybe. Ezen feltételek nagymértékben hozzájárulnak a turisták költésének és mozgásának térbeli eltéréseihez, miközben a tartózkodási idejük meghosszabbítását is elősegíthetik. (Michalkó, 2007a) 


\section{Anyag és módszer}

A kutatás területe a romániai Bihar megye és annak önkormányzati szintje, mely a NUTS rendszer szerinti LAU2-es besorolásnak (Eurostat, 2021) felel meg. A román-magyar határ menti térség egyik legjelentősebb városa, valamint a Partium központjaként is számon tartott Nagyvárad a turizmus szempontjából is kiemelet megyei és nemzeti szinten egyaránt. Bihar megye a Partium legnagyobb kiterjedésú megyéje, mely területe az ország 3,2\%-a, összesen $7535 \mathrm{~km}^{2}$-rel. Összesen 101 önkormányzatból tevődik össze, melyből négy municípium, Nagyvárad megyeszékhellyel együtt, majd hat városi rangú és 91 község rangú önkormányzat (Bakk-Süli-Zakar-Szilágyi, 2019).

Az önkormányzatokat négy fő potenciális desztináció típusba csoportosítottam, azok elhelyezkedése és turisztikai erőforrásai alapján, melyek nem alkotnak feltétlen földrajzilag egybefüggő területet, ami azért is indokolt, mert a turisztikai potenciál erősségét meghatározó 142/2008-as sürgősségi kormányrendelet (Szerző nélkül1, 2021) is önkormányzati szinten tárgyalja a turisztikai erőforrások megtalálható típusait:

- városi desztináció - municípium vagy városi ranggal rendelkező települések, összesen 10 önkormányzat: Nagyvárad, Belényes, Margitta, Nagyszalonta, illetve Élesd, Érmihályfalva, Diófás, Székelyhíd, Vaskoh és Vaskohsziklás.

- gyógy- és fürdő üdülőhely - termál gyógyvízzel, fürdővel és szakosodott szálláshellyel rendelkező önkormányzatok területei, összesen öt önkormányzat: Alsótótfalu, Madarász, Tenke, Vámosláz és Váradszentmárton

- hegyvidéki desztináció - magassági szint, valamint a hegyvidéki turisztikai attrakciókhoz való közelsi elhelyezkedés alapján 31 önkormányzat: Almaszeg, Alsóbiharkristyór, Barátka, Bihardobrosd, Biharkaba, Biharlonka, Biharrósa, Bondoraszó, Bontesd, Csarnóháza, Esküllő, Felsőderna, Felsőmezős, Kerpenyéd, Kisősi, Kispapmező, Köröstárkány, Magyarremete, Nagybáród, Rény, Rév, Robogány, Sólyom, Sólyomkővár, Sonkolyos, Szászfalva, Tataros, Tisztásfalva, Várasfenes , Vasaskőfalva, Vércsorog

- falusi desztináció - alföldön vagy dombvidéken elhelyezkedő települések, melyek nem a hegyvidéki túraútvonalak kiinduló pontjai, összesen 55 önkormányzat sorolandó ide: Almamező, Alsókocsoba, Alsólugos, Bályok, Bátor, Belényesirtás, Belényesújlak, Berettyószéplak, Bihar, Biharhosszúaszó, Biharpoklos, Biharszentandrás, Bors, Cécke, Cséffa, Diószeg, Dragánfalva, Drágcséke, Érábrány, Érbogyoszló, Érkörtvélyes, Érsemjén, Érszőllős, Értarcsa, Feketekápolna, Fugyivásárhely, Gyapju, Hagymádfalva, Hegyközcsatár, Hegyközszáldobágy, Illye, Keményfok, Kiskereki, Kiskopács, Körösgyéres, Köröskisjenő, Magyarcséke, Mezőszakadát, Mezőtelegd, Miklóirtás, Nagyürögd, Oláhszentmiklós, Olcsa, Paptamási, Pusztahollód, Sólyomkővár, Szalacs, Szalárd, Szentjobb, Szombatság, Tasnádbajom, Tóti, Tulka, Vedresábrány és Vizesgyán.

A kutatás szekunder adatforrások felhasználásával valósult meg. A szuprastruktúra értelmezésére és jellemzőire vonatkozó szakirodalmi kutatást követően a szálláshely és vendéglátó szolgáltatók leltárát állítottam össze Bihar megyére, azokat TEÁOR kódjuk szerint és települési szinten csoportosítva végeztem az adatbázis építést, majd az adattisztítást. Az összes romániai vállalatot tartalmazó Lista Firmelor Din România (Listafirme, 2021) előfizetés ellenében elérhetô online adatbázist vettem elsődlegesen alapul, melyben a tevékenységi kategóriára és megyei szintre el tudtam különíteni a vállalatokat, valamint azok elérhetőségét, árbevételét és átlag alkalmazotti létszámát 20052020-as időszakban. A honlapot a Romániai Pénzügyminisztérium (2021) honlapján elérhető adatokkal bővítettem, valamint, ahol hiányos információkat találtam csak, az előző adatbázis tükrében, azokat még négy, a romániai vállalatokat és azok adatait tartalmazó online adatbázisból nyertem ki, 
melyek a következók: Risco (Risco, 2021), Lista-Firme-Romania (ListaFirmeRomania, 2021), Termene (Termene, 2021), Totalfirme (Totalfirme, 2021). Az adatgyújtés 2020. szeptember 20.2021. június 30. között zajlott, mivel a vállalatok május végéig voltak kötelesek 2020-ra vonatkozó könyvelési adataikat leadni az állami szerveknek, s júniustól vált elérhetővé online.

A 385 szállásszolgáltató esetén az 55-ös tevékenységi kód szerint (KSH, 2021) négy csoportba kerültek:

- 5510 - Szállodai szolgáltatás

- 5520 - Üdülési, egyéb átmeneti szálláshely-szolgáltatás

- 5530 - Üdülési, egyéb átmeneti szálláshely-szolgáltatás

- 5590 - Egyéb szálláshely-szolgáltatás

Az 55-ös csoport vállalatai közül négy, Bukarestben bejegyzett cég leányvállalata található, melyeken csak összesített adataik vannak, így nem kerültek be az árbevétel, valamint az éves átlag alkalmazotti létszám összesítésébe, ennek megfelelően Nagyvárad esetén a Continental Forum Oradea 355 férőhellyel (Continental, 2020), valamint Váradszentmárton községben a 460 férőhelylyel rendelkező Hotel Ceres (tbrcm, 2020), a 868 férőhelyet számláló Hotel Padiș (2020) és a Hotel Muncel (2020) árbevételeinek és alkalmazottaik számának adatai nem szerepelnek a vállalati leltárban, csak tevékenységi besorolásuk van feltûntetve a szálláshelyek kategóriában önkormányzati szinten.

A 2020ban is múködő vagy akkor bejegyzett 1066 vendéglátó vállalkozás az 56-os kódhoz besoroltak négy csoportja (KSH, 2021):

- 5610 - Éttermi, mozgó vendéglátás

- 5621 - Rendezvényi étkeztetés

- 5629 - Egyéb vendéglátás

- 5630 - Italszolgáltatás

Az eredmények kartográfiai módszer segítségével szemléltetésre kerültek, melyekhez az általam szűrt, tisztázott és kielemzett adatokat használtam fel.

\section{Eredmények}

\section{Bihar megye szálláshely-szolgáltatás struktúrájának jellemzói}

A szálláshelyek fő csoportját a kereskedelmi szálláshelyek képzik, amelyek az idegenforgalom szempontjából is jelentősek, illetve fogalma alatt kizárólag a regisztrált szálláshelyekről lehet beszélni turizmuselméleti szempontból, melyek a helyi önkormányzattól múködési engedélyt kapnak és üzemeltetője elvégzi az osztályba sorolását. (Michalkó, 2007a). Hivatalos adatokat a Román Nemzeti Statisztikai Intézet honlapján lehet elérni a kereskedelmi szálláshelyek kínálati és keresleti trendjeinek változásáról, 1990-től kezdődően napjainkig.

A szálláshelyek száma mellett kiemelt szerepet tölt be, a turizmusföldrajzi elemzések alapjaként, a rendelkezésre álló férőhelyek mennyisége, mert árnyaltabban ábrázolja a kínálati oldal jellegét és annak területi megoszlását. A kereskedelmi szálláshelyek csoportjába tartozó egységek nagy részének létesítését jelentősen befolyásolják a táji adottságok és a célterületen található turisztikai erőforrások tulajdonságai, bár a szállodák és panziók esete kivételt képez (Michalkó, 2007b). Például Bihar megye Váradszentmárton községében is a gyógyszállodák telepítésénél a desztináció erőforrásai közül elsődlegesen a gyógytényezőket vették figyelembe. 
A romániai adatközlés (INSSE, 2021) a kereskedelmi szálláshelyek csoportjába, a Bihar megyében jelen levők közé tizenkét típust sorol, kizárólag legalább 5 férőhellyel rendelkező egységeket, meghatározva azok jellemzőit: szálloda, turistaszálló, apartmanszálloda, motel, fogadó, villa, faház, bungaló, kemping, gyerektábor, panzió és agroturisztikai panzió. Ennek megfelelően, összesen 283 bejelentett szálláshely volt regisztrálva 2020-ban a Statisztikai Intézet által, a megye 45 önkormányzatában, mely területi szempontból az önkormányzatok számának 44,55\%-a. Az előző éves adatokkal összehasonlításban a regisztrált szálláshelyek számában 10,55\%-os növekedés mutatkozott, illetve 2019-ben a megye 39 önkormányzatának területén regisztráltak szálláshelyeket. A turisztikai kapacitás tekintetében a rendelkezésre álló működő férőhelyek éves adatait vizsgálva részben ellentétes trend látható a 2019-2020-as időszakban. A 45 önkormányzat területéből három-három terület egység nem azonos az adatbázisban 2020-ban, viszont a kapacitás tekintetében mindössze 37 település-együttesen volt regisztrált működő-férőhely, mely 8,8\%-os növekedést jelentett 2019-hez viszonyítva. A kapacitás mértéke viszont 31,58\%-os visszaesést mutatott 2020-ban az előző évhez képest, 3503 220-ról 2396 940-re, melynek megfelelően a 2011 elötti szintre esett, ahol a 2008-as válságot követően volt mérhető két évben hasonló érték. Ha a kutatásban vizsgált 2005-2020-as periódust vesszük figyelembe e két mutató esetén, akkor a szálláshelyek számát tekintve 85-rôl 283ra emelkedett, azaz 232,92\%-os növekedés mutatkozott a megyében, illetve 23ról 45re nőtt az önkormányzatok száma, mely területén volt regisztrálva a szálláshely.

A rendelkezésre álló működő férőhelyek éves összesítését tekintve 6,97\%-os visszaesés mutatkozott 2020-ban 2005-ös évhez viszonyítva, mikor 2576583 volt, azonban 2005-ben 16 önkormányzat területén regisztrálták a szállás kapacitás összegét, míg 2020-ban 37 területén, mely 131,25\%-os növekedést jelentett a területi terjeszkedés szempontjából. Az adatok arra a következtetésre vezetnek, hogy alacsonyabb kapacitású szálláshelyek nyiltak meg, példádul az agroturisztikai panziók esetén, melyek a legnagyobb számban és a legkisebb megengedett kapacitással múködnek Bihar megyében. Ezek száma 2019-2020 között 13,39\%-os növekedést mutat 144 egységgel, a kapacitást tekintve 14,21\%-os növekedést 3103 hellyel és múködő férőhelyek éves adatait tekintve 25,21\%os visszaesést láthatunk, 588 477-ről 440 097-re, melyre a pandémiának nagy hatása volt, a kötelező zárva tartási periódus miatt. A második legnagyobb számban jelen levő egység típus a szálloda, 53 szolgáltatóval, majd a panziók, 28 egységgel, illetve a turistaszálló, 11 egységgel. A többi típushoz kevesebb, mint 10 szolgáltató vállalat tartozik egyész megyére vonatkoztatva. A szállodák a kapacitás tekintetében kiemelt helyet képviselnek, melyek száma két új egység megnyitásával 51 ről 53-ra emelkedett, mely 3,91\%-os növekedést, a férőhelyek száma 8446 lett 8343-ról, e szerint 1,23\%-os növekedést, illetve múködő férőhely kapacitás éves adatait tekintve 32,8\%-os visszaesést mutatott 2020-ban az előző évhez viszonyítva, szám szerint 2288 328-ról 1537 655-re. A turistaszállók kivételével, mely esetében 8,58\%-os visszaesést volt mérhető 664-ről 607-re, minden szálláshely típus legalább a 2019-es évben mért férôhely számot nyújtotta vagy növekvő befogadóképességet, a 2020-as évben, ennek ellenére minden szálláshely típusnál csökkenő tendenciát mutatott a 2020-as évben mért múködő férőhely kapacitás, melyre a járványügyi korlátozások mindenképpen hatást gyakoroltak.

\section{A müködö kereskedelmi szálláshelyek tevékenységi alágazati megoszlása - a vállal- kozások területi jellemzói}

A tanulmányban vizsgált 385 szálláshely szolgáltató a megye 101 adminisztratív területi egységének szintjén elemezve nagy eltérések mutatkoztak önkormányzatonként a még 2020-ban is múködő 
vállalatok esetén. Szálláshelyek tekintetében 30 önkormányzat nem rendelkezett szálláshely szolgáltatással egyáltalán, mely a fentiekben említett négy potenciális desztináció típus esetén kétharmadban a hegyvidéki és egyharmadban a falusi turizmusra alkalmas területek csoportja.

Megyei szinten a vállalatok tevékenységi kód szerinti besorolásának megfelelően az 5520 Üdülési, egyéb szálláshely- szolgáltatás kategóriába a vállalatok 43,12\%-a tartozik, az 5510 Szállodai szolgáltatás csoport 28,83\%-ban van jelen, az 5590 Egyéb szálláshely-szolgáltatás kategóriába 25,19\% tartozik, majd a legkevesebb cég az 5530 Kempingszolgáltatás csoportban van nyilvántartva, mindössze 2,86\%-kal. A vállalati típus megyei, desztináció szerinti és Nagyváradon belüli megoszlását az 1. ábra szemlélteti, melyben a 2020-as adatok szerint a cégek tevékenységi kódjainak megfelelóen, számuk szerinti összesítésük szerepel.

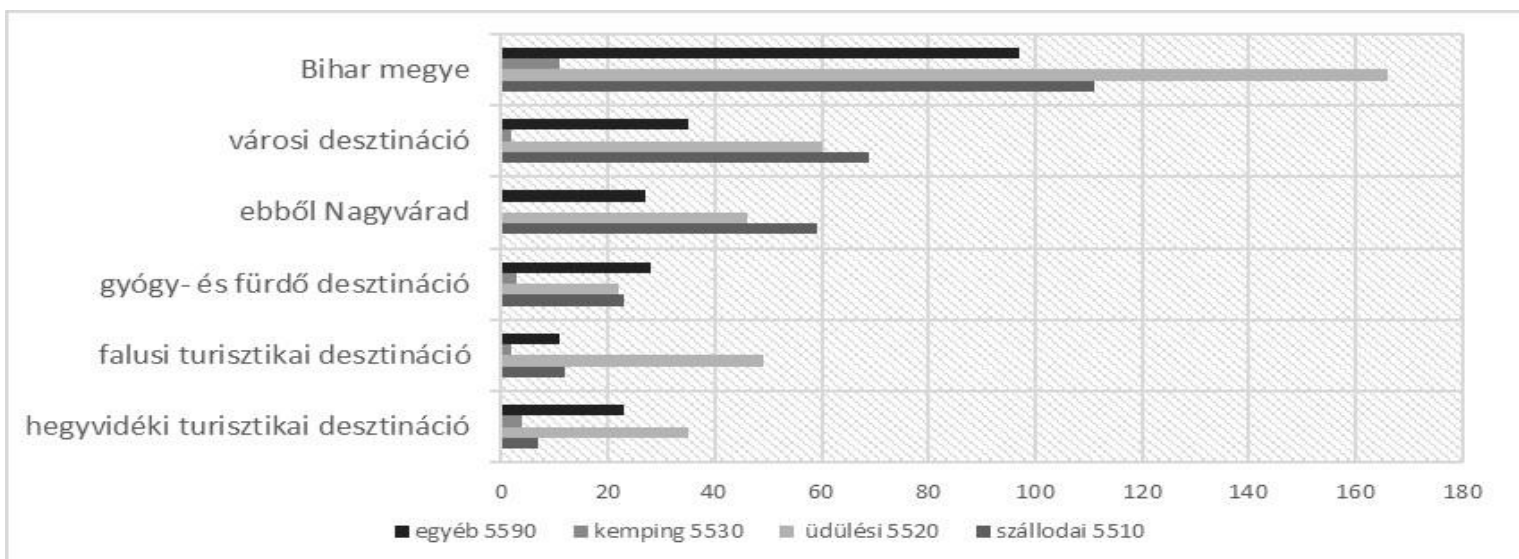

1. ábra: A szálláshely-szolgáltató vállalatok desztináció típus szerinti megoszlása, a vállalatok tevékenységi kódjának megfelelően, 2020-ban (vállalatok száma)

Forrás: Saját adatbázis. Saját szerkesz̨tés

A legnagyobb súllyal a városi desztinációk 166 szolgáltató egysége jelent meg, 43,12\%-os arányban, melyek közül Nagyvárad kiemelkedik 34,29\%-kal megyei szinten és 79,52\%-os aránnyal a desztináció tekintetében. Arányosabb a megoszlás a többi kategória között: hegyvidéki 69 egysége 17,92\%-kal, a gyógy- és fürdő üdülőhely 76 egysége 19,74\%-kal, illetve a falusi desztinációk 74 szolgáltatója 19,22\%-kal. A gyógy- és fürdő desztinációban, a megyeszékhelyen metropolitán övezetében elhelyezkedő Váradszentmárton község emelkedett ki, mely turisztikai jelentőségében is meghatározó, mivel Félixfürdő nemzeti érdekeltségű, míg Püspökfürdő helyi érdekeltségű desztináció, a 916/2018 Határozat alapján, a bejegyzett szálláshelyek tekintetében a gyógy- és fürdő üdülőhely kategórián belül első helyen szerepelt 67 vállalattal, azaz 88,16\%-os arányban, míg megyei szinten nézve a második önkormányzat volt $17,40 \%$-os aránnyal.

Az agroturisztikai panziók is az 5520 tevékenységi kód alatt vannak bejegyezve, mely a nemzeti statisztika szerint mindenképpen kiemelkedő számban vannak jelen (INSSE, 2021), ennek megfelelően jól látható, hogy a falusi és a hegyvidéki desztinációk esetén is dominált e tevékenységi kategória a saját típusaikon belül, előbbinél 66,22\%-ban 49 egységgel, utóbbinál 50,72\%-ban 35 egységgel. Megjegyzendő, hogy a hegyvidék esetében is falusi településekről beszélünk, ezzel is indokolható az 5520-as kategória nagy mértékủ jelenléte, illetve, hogy mindkét célterület típus esetén tíz szálláshely szolgáltató egységnél kevesebb volt bejegyezve minden önkormányzat területén.

A 2. ábrán szereplő térkép bemutatja a szálláshelyek TEÁOR kód szerinti megoszlását önkormányzatra bontott léptékben, valamint a desztináció típusok elhatárolásával. Jól kirajzolódik egy törésvonal, mely a megye közepét szeli át a hegyvidék és alföldi területek átmeneti részénél, ahol 
nincs egyetlen bejegyzett szálláshely-szolgáltató sem. Ezeken kívül a megye déli és északkeleti határmenti önkormányzatainak túlnyomó részében szintén nem volt bejegyezve 2020-ban is még mûködő szálláshely.
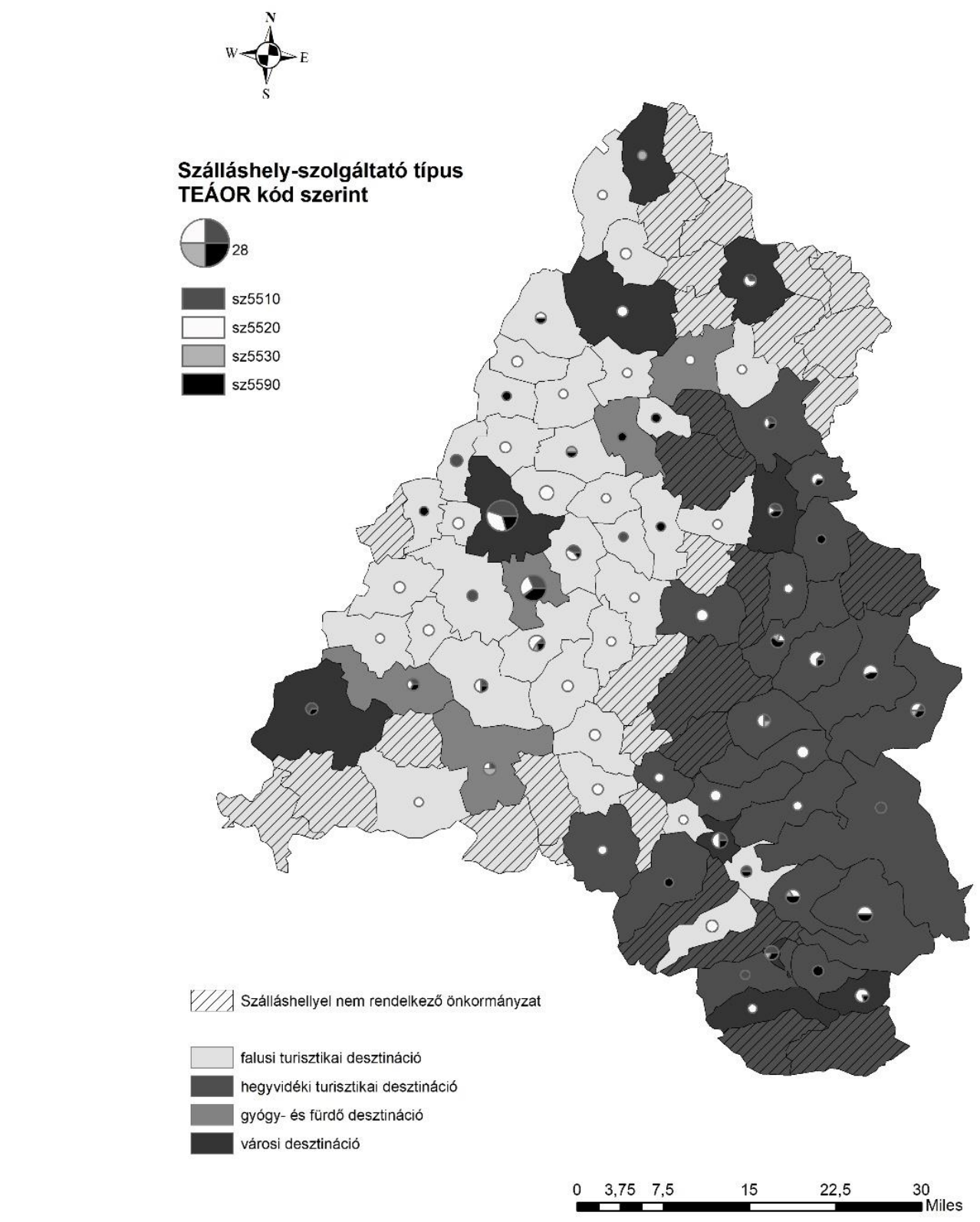

2. ábra: Szálláshely-szolgáltató vállalatok ágazat szerinti területi megoszlása 2020-ban Forrás: Saját adatbázis. Saját szerkesz̧tés

Az önkormányzati lebontásban a szálláshelyek területi ágazati megoszlását figyelembe véve a szolgáltatók számával arányos az ábrázolt körök területe, mely szemlélteti Nagyvárad és Váradszentmárton kimagasló súlyát megyei szinten. A három municípium közül Belényes emelkedett ki 8 vállalattal, majd Margitta és Nagyszalonta 3-3 szolgáltatóval. A városok esetén Vaskohsziklás 6, Élesd és Diófás 5-5 szolgáltatóval rendelkezett, valamint Székelyhíd 2, Érmihályfalva és Vaskoh 1-1 vállalattal. A falusi desztináció esetén ötnél nagyobb cég számmal Almamező, Fugyivásárhely és Hegyközszáldobágy rendelkezett, a többi öt szolgáltatónál keveseb- 
bel. A gyógy- és fürdő desztinációk tekintetében, Váradszentmártont kivéve, ötnél kevesebb bejegyzett szálláshely-szolgáltatóval rendelkeztek az önkormányzatok. A hegyvidéki desztinációk esetén 5-8 közötti szolgáltató egységgel Sonkolyos, Vasaskőfalva, Barátka, Bontesd, Csarnóháza és Rév rendelkezett, a többi ötnél kevesebbel.

A vizsgált, 2020-ban is múködő, vállalatok összesített árbevétele 191037282 lej összegű volt, mely tekintetében 2020-ban 36,23\%-os csökkenés volt mérhető, a 2019-es árbevételekhez képest megyei szinten, míg a vállalatok száma viszont 8,15\%-kal nôtt. A 2005-2008-as időszak hullámzó értékeket mutatott, 2006-ban 3,03\%-os csökkenés mutatkozott 2005ben összesített 77023951 lejhez viszonyítva, majd a 2006-2008-as periódusban 37,36\%-kal nőtt az árbevételek összege. A 2008as válságot követően 2009-ben enyhén visszaesett az árbevételek összege, 3,53\%-kal, majd 2010től ismét növekedés volt mérhető. A 2014-2016-os és 2017-2019-es időszakokban exponenciális növekedés mutatkozott, majd a pandémia megtörte ezt a tendenciát. Mindazonáltal megjegyzendó, hogy a vizsgált vállalatok 1989-2020 között voltak bejegyezve. A legtöbb bejegyzett cég 2006-ban, 21 darab, illetve évi 29-34 közötti számban a 2016-2020-as időszakban. A desztinációk tekintetében a 90-es évek óta működő vállalatok mindegyik kategóriában megtalálhatóak, bár 2015-tôl lett bejegyezve a falusi desztinációkban a cégek 59,46\%-a, a hegyvidéki desztinációkban a 44,93\%-a, a gyógy- és fürdő üdülőhelyeken a 38,16\%-a, illetve a városi desztinációkban a 39,16\%-a. Ennek megfelelően szépen kirajzolódik, hogy minden desztináció típusban jelentős számbeli növekedés mutatkozott a vállalatok tekintetében 2015-től, valamint a fentebb említett árbevételek 123,53\%kal való növekedését indokolja a vállalatok számának 64,81\%-os gyarapodása is 2019-ig bezárólag.

Bihar megye szintjén a vizsgált vállalatokra az átlagos évi alkalmazottszám 2005-2007 között 30,24\%-ban csökkent 2335 főről 1629-re, majd a 2008-as válságot követően mérsékelt, azaz 2,12\%os növekedés mutatkozott, mellyel szemben 2014-2016 között exponenciális növekedés következett 29,02\%-kal, majd 2016-2019 között 5,95\% emelkedés követett. 2020-ban 8,27\%os létszám csökkenés volt mérhető a pandémia hatásának köszönhetően az előző évben regisztrált 2369-ről 2173-ra, azzal szemben, hogy a vállalati egységek száma növekedett. A Váradszentmártonban bejegyzett cégek az alkalmazottak 99,48\%-át foglalkoztatták, a desztináció típuson belül, összesen 1256 főt, és megyei szinten is a legnagyobb aránnyal rendelkeznek, összesen 57,80\%-kal. Nagyvárad esetén 84,80\%-át foglalkoztatták az itt bejegyzett cégek a városi desztináció típuson belül, összesen 558 főt, megyei szinten mérve pedig 25,68\%-át. Ezért értelemszerü, hogy a legnagyobb létszámcsökkenés e két önkormányzaton belül mutatkozott 2020-ban. Nagyürögd jelent meg 50 főnél nagyobb alkalmazotti létszámmal, majd 20-49 között Bors, Belényes, Csarnóháza, Sonkolyos, Nagyszalonta és Fugyivásárhely. Összesen öt önkormányzatban alkalmaztak átlag 10-16 közötti alkalmazottat, ezek Érmihályfalva, Vaskohsziklás, Margitta, Rév és Madarász voltak. További 33 önkormányzat 10 alatti alkalmazottal rendelkezett, illetve 24-nél nem volt bejelentve éves átlag alkalmazotti létszám, csak az üzletvezető szám volt adott egy-két fővel, melyből 11 esetén a teljes 20052020-as periódus alatt egyáltalán nem rendelkeztek alkalmazottal, sem árbevétellel, ami azzal indokolható, hogy egy kivételével mind 2017 után lett bejegyezve és valószínűleg nem kezdték el még a tevékenységet.

\section{A müködö vendéglátó egységek területi szerkezeti jellemzói a 2005-2020-as idó- szakban}

Az 1066 étkeztetési és italszolgáltatást nyújtó vállalkozás esetén, melyek bejegyzésüktől fogva még 2020-ban is múködtek, csupán kilenc önkormányzatban nem volt bejegyezve ilyen tevékenységú cég, ebből hét a falusi, egy a hegyvidéki és egy a gyógy- és fürdő turizmus múködtetésére alkalmas 
területen található. Ahogy az a 3. ábrán is látható, összességében az 5610 csoporthoz tartozó éttermi, mozgó vendéglátás 579 egysége 54,32\%-kal és az 5530-as csoporthoz tartozó italszolgáltatók 414 egysége 38,84\%-kal voltak legnagyobb mértékben jelen megyei szinten, bár a desztinációkra való lebontásban egyaránt domináltak. Utóbbit az is indokolja, hogy legtöbb település rendelkezik bárokkal vagy kocsmákkal, ennek megfelelően arányuk is magas. Alacsony jelenléttel szerepelt megyei szinten az 5621 Rendezvényi étkeztetés kategória 53 egysége 4,96\%-kal, és az 5629 Egyéb vendéglátás 20 egységgel, utóbbi a legalacsonyabb arányban volt jelen 1,88\%-kal.

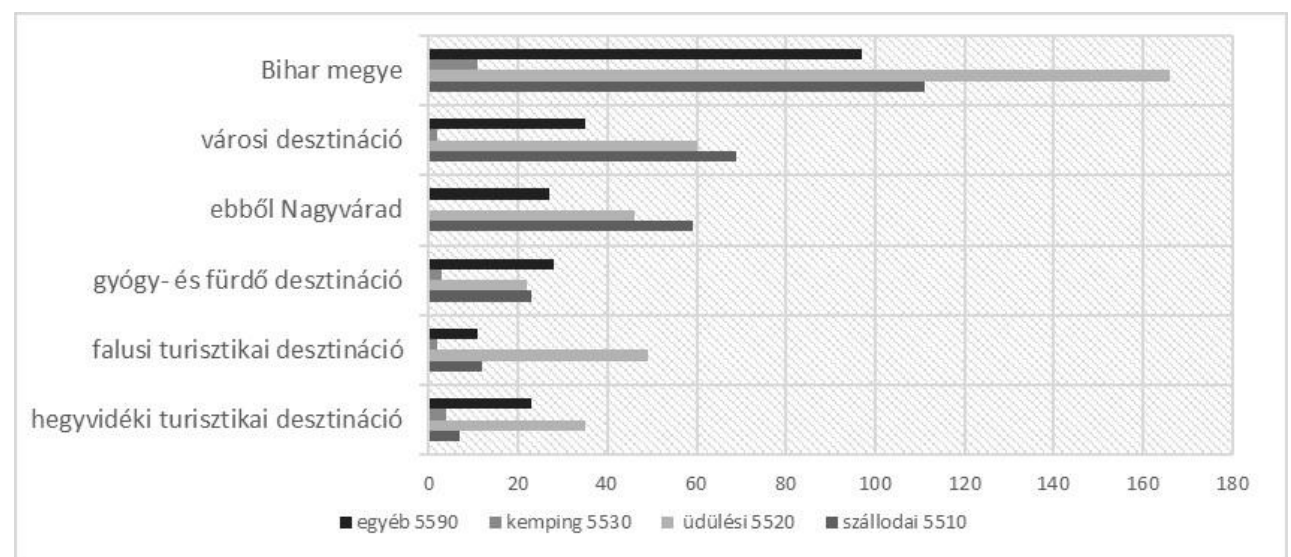

\section{3. ábra: Vendéglátó egységek megoszlása desztináció típusra bontva, a szolgáltatók tevé- kenységi kódjának megfelelően, 2020-ban (vállalatok száma)}

Forrás: Saját adatbázis. Saját szerkesz̨tés

A vendéglátói vállalatok 57,41\%-a 2014-tôl lett bejegyezve, melyből 2018-2019 között volt a legnagyobb a cégalapítások aránya, összesen 290 cég, mely 27,20\%. 2020-ban 78 szolgáltató nyitott meg, azaz a vállalatok 7,32\%-a. 1997-2002 között évente kevesebb, mint 10 vállalat jött létre a vizsgált cégek körében.

A 2020-as évben a teljes vendéglátó egység szám 50,19\%-a a megyeszékhelyen volt bejegyezve, szám szerint 535 cég, ennek is köszönhető, hogy a városi desztináció típus esetén volt a legnagyobb a vállalatok számának aránya 707 egységgel, mely megyei szinten összesen 66,32\%-ot tett ki. Desztináció típusán belül Nagyvárad 75,67\%-os vendéglátói aránnyal volt jelen. Tevékenységi besorolás szerint 52,90\%-ban az 5610-es csoporthoz tartozó cégek emelkednek ki, majd ezt követi 39,46\%-kal az 5630-as kategória, utána 5,37\%-kal következik az 5521-es és legkisebb aránnyal pedig az 5629-es csoport, mindössze 2,26\%-kal.

A falusi desztináció csoport a második legtöbb céggel rendelkező kategória lett, a 220 vállalat megyei viszonylatban 20,64\%. Tevékenységi ágazati megoszlás tekintetében az éttermi, mozgó vendéglátás 56,82\%-ban, az italszolgáltatás 39,1\%-ban, a rendezvényi étkeztetés 3,18\%-ban és legkevesebb számban, $0,91 \%$-kal, az egyéb vendéglátás szerepel.

Kevesebb, mint 100 vállalattal rendelkezett a másik két típus, a hegyvidéki desztináció 75 céggel 7,04\%, míg utolsó a gyógy- és fürdő üdülőhely köre, a 6\%-ot kitevő 64 céggel. Utóbbi esetén Váradszentmárton ismét kiemelkedik, mivel a vállalatok 71,88\%-a itt lett bejegyezve a desztináció típuson belül. A hegyvidék esetén 46,67\%-ban az 5610-es és 45,33\%-ban az 5630-as szolgáltatók múködtek, míg az 5621-es kategória 6,67\%-ot és az 5629-es pedig 1,33\%-ot reprezentált. A gyógyés fürdő üdülőhelyek tekintetében az 5610-es csoport 70,31\%-ban, az 5630-as 23,44\%-ban, az 5621-es 4,69\%-ban, illetve az 5629-es 1,56\%-ban volt jelen 2020-ban.

A 2020-ban is múködő vállalatok régiségét tekintve 1991-től 2020-ig lettek bejegyezve, melyek esetén az éves legtöbb cégalapítás 163 darab volt 2019-ben, illetve kiemelendő, hogy 2018 és 2019- 
ben alapították több, mint negyedét, azaz 27,2\%-át. A járványhelyzet ellenére, 2020-ban szintén növekedett a vállalatok száma 78 vendéglátó egységgel. A 1997-2002 közötti időszakban nyitott meg évente a legkevesebb vállalat, évi 10-nél alacsonyabb számban. Fokozottabb növekedés öszszességében 2014-től mérhető és 2014-2020 között lett alapítva a kutatás alapját képző cégek $57,41 \%-$ a.

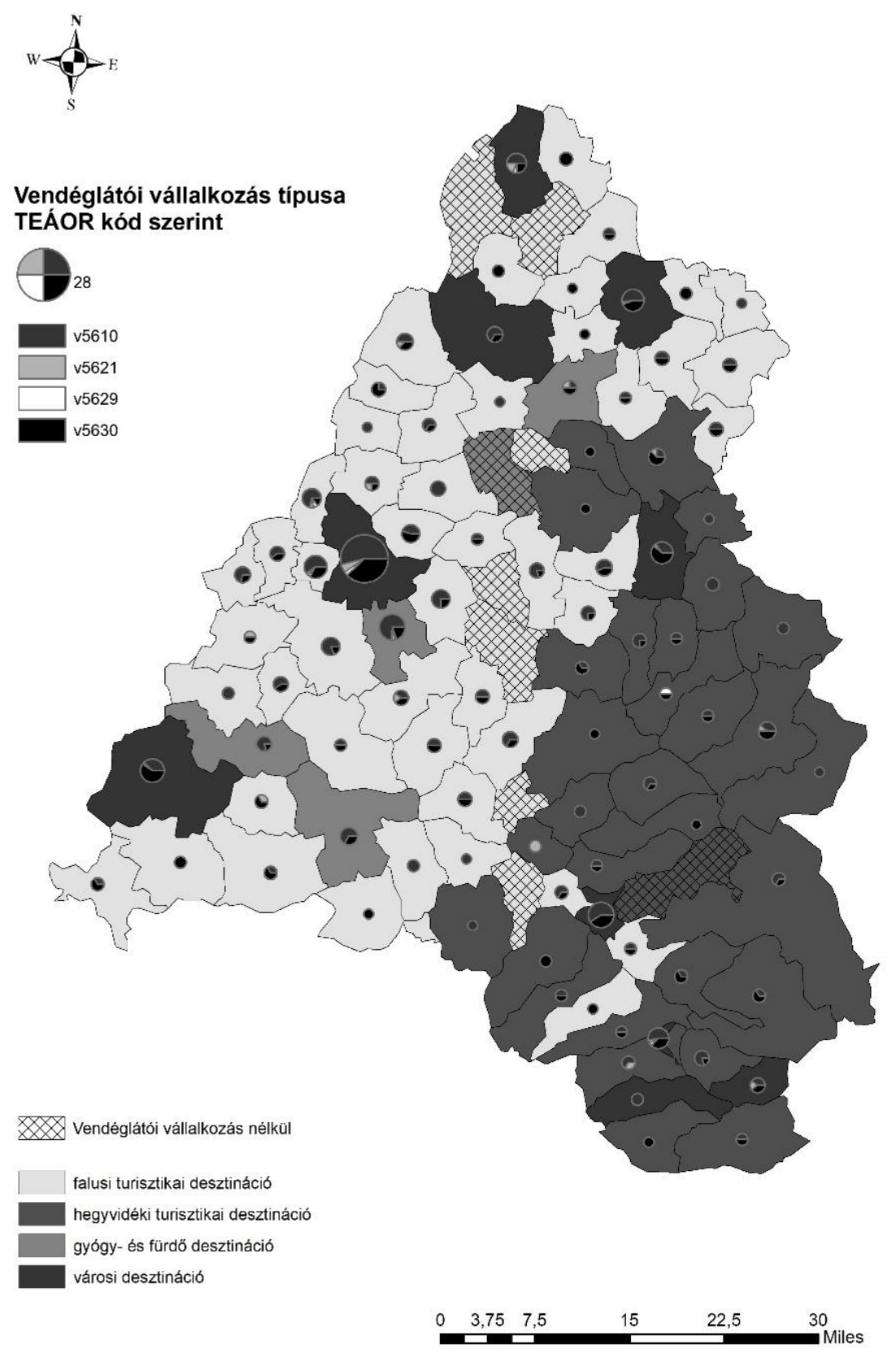

4. ábra: Vendéglátói vállalatok ágazat szerinti területi megoszlása 2020-ban Forrás: Saját adatbázis. Saját szerkesztés

A 4. ábra térképe szemlélteti a vendéglátói vállalatok önkormányzatokra és desztináció típusokra bontott, TEÁOR kód szerinti megoszlását, a 2020-as évre vonatkozóan. A 9 önkormányzat, ahol nincs bejegyzett vendéglátóhely, elszórtan helyezkedik el egymáshoz képest a megye közepét átszelve észak-dél irányban, melyeknél két önkormányzat esetén van egybeesés a szálláshely szolgáltatókban hiányos területtel, ezek pedig Értarcsa és Belényesújlak. 
A térkép szemlélteti önkormányzati szintű területi lebontásban, a szolgáltatók számával arányos ábrázolás alapján, a vállalatok ágazati megoszlását, melynek megfelelően a megyeszékhely súlya nagy mértékben kiemelkedik megyei szinten, első helyen szerepelt az önkormányzati hierachiai sorrendben. A második legtöbb vendéglátói vállalkozással Váradszentmárton rendelkezett 2020-ban, viszont mindössze 46 vállalattal, azaz 4,32\%-os részaránnyal, ezért nem lehet a szálláshelyek esetével párhuzamot vonni, bár turisztikai jelentősége e tényező által is kirajzolódik. A következô négy önkormányzat tartozik a 25-44 cég szám közötti értékkel rendelkezők közzé: Belényes 44, Nagyszalonta 32, Biharszentandrás 27 és Margitta 25 szolgáltatóval. A 15-24 vállalat szám kategóriába Élesd 23, Vaskohsziklás 19 és Érmihályfalva 16 céggel tartozik.

A városi desztinációk közül még 10 céggel sem rendelkezett: Székelyhíd 6, Diófás 5 és Vaskoh 2. A hegyvidéki desztináció esetén egyedül Barátka 10 céggel és Almaszeg 8 céggel emelkedik ki, a többi 1-5 közötti vendéglátói szolgáltató számmal rendelkezett 2020-ban. A falusi desztinációk tekintetében 43 önkormányzat 10-nél kevesebb vendéglátóval rendelkezett, ezek közül kivétel a fentebb említettek mellett még: Bors 14, Fugyivásárhely 12, Nagyürögd 11 és Hegyközszáldobágy 11. A gyógy és fürdő üdülőhelyek esetén három további önkormányzatban volt vendéglátói szolgáltató: Tenke 9, Madarász 5 és Vámosláz 4.

A 2020-as megyei összesített árbevételt figyelembe véve, mely 296497570 lej volt, 33,22\%-os visszaesés mutatkozott 2019-hez képest, bár a vállalatok száma 7,32\%-kal nőtt. A 2005-2008 között időszakban az árbevételek összege 48266519 lejről 77,27\%-kal nőtt, majd, a válság utáni időszakban, 2009-ben 2,5\%-kal csökkent az előző évhez viszonyítva és 2010-ben is alacsonyabb volt 1,22\%-kal, mint 2008-ban. 2011-2019 között megszakítatlan növekedési periódus mutatkozott, 2011-2014-es időszakban 44,33\%-os, majd 2015-2019 között 131,25\%-os növekedéssel, melyet a pandémia a 2017 előtti szintre vetett vissza. Desztináció típus tekintetében a nagy vállalati létszámnak köszönhetően a városi kategória messzemenően kimagasló értékeket mutatott a teljes időszak alatt, a 2020-as megyei teljes árbevétel 72,38\%-ával, ebből Nagyvárad részaránya 60,27\% volt megyei szinten és $83,27 \%$ a desztináció típuson belül. A vállalatok számával is arányosan, a második legtöbb árbevétellel a falusi desztináció rendelkezett, a 35438588 lej 11,95\% volt, majd a gyógyés fürdő üdülőhely típus következett 27464197 lejjel, azaz 9,26\%-kal, végül a hegyvidéki desztinációk 6,41\%-kal, 18995081 lejjel. A szolgáltatók számának arányával ellentétben a gyógyés fürdő üdülőhely kategória megelőzte a hegyvidéki típust a 2020-as árbevételek esetén.

Az átlagos évi alkalmazottak számában 2005-2008 között mérsékelt fluktuáció mutatkozott a négy év alatt, majd 2008-tól 2019-ig megszakítás nélküli növekedés. 2008-2013 között 42,08\%-os, majd 2013-at követően 2019-ig 83,75\%-os növekedés követhető nyomon a vizsgált cégek esetén. A pandémia nagy mértékben rányomta bélyegét a vendéglátásban dolgozó alkalmazottak számának változására, szintén 2017 előtti értékre vetette vissza azt 15,65\%-os mértékben 2019-hez képest, azaz 3822-ről 3224-re. Desztináció típus szerinti megoszlás tekintetében az összes foglalkoztatott $72,43 \%$-át a városi, másodikként 11,17\% 0 -át a falusi, majd 10,89\%-át a gyógy- és fürdő, végül 5,52\%át a hegyvidéki desztinációkban alkalmazták 2020-ban. A 2019-es adatok szerint a gyógy- és fürdő üdülőhelyek voltak a második helyen, azonban egyedül a falusi desztináció szintjén mutatkozott növekedés 2020-ban, mely 2,27\% volt, így a többi visszaesésével megváltoztatta a rangsort a desztináció típusok felosztásában.

Nagyvárad rendelkezett a legtöbb vendéglátásban dolgozó alkalmazottal, 1881 fővel, mely a megye szintjén $58,34 \%$ és desztináció típusán belül 80,56\%. Váradszentmárton került a második helyre 282 fővel, ami megyei szinten 8,75\%, desztináció kategóriáján belül 80,34\%. Belényes 121 és Nagyszalonta 108 foglalkoztatottal, majd Barátka 77, Margitta 72 és Vaskohsziklás 51 alkalmazottal rendelkezett. Összesen 11 önkormányzatban 20-49 közötti éves átlag alkalmazotti szám volt, majd 
megint 11-ben 10-19 között és további 46-ban 1-9 közötti. Nem volt egy foglalkoztatott sem bejelentve 2020-ban 17 önkormányzat területéről, melyből négy esetén a vizsgált időszakban nem voltak adatok megadva, ami annak is köszönhetô, hogy öt évesnél fiatalabb vagy épp frissen bejegyzett cégek köre tartozik hozzá.

\section{Összegzés és következtetések}

A szálláshely-szolgáltatók tekintetében a megye önkormányzatainak 29,7\%-ban nem található egyáltalán bejegyzett vállalat, mely 2020-ban még múködött. A Román Nemzeti Statisztikai Intézet szálláshely-kínálatra vonatkozó adatai lényegesen kevesebb egységet regisztráltak, mint az aktív vállalatok bejegyzett csoportja a Pénzügyminisztérium adatbázisában, ezért javasolt a szorosabb kooperáció a nemzeti intézmények szintjén a helyesebb információ közlés érdekében. Azonban meg kell említeni, hogy az ötnél kevesebb férőhellyel rendelkező egységeket nem veszik figyelembe.

A vendéglátói cégek esetében az önkormányzatok mindössze 8,91\%-ban nincs bejegyzett vállalat, azonban kiemelendő, hogy ezen egységek legtöbb területen valószínúleg inkább a helyi lakosság igényeinek kielégítésére szolgálnak, főképp a kisvárosok és községek esetében, illetve az 5530-as kategória tekintetében.

A kutatásnak megfelelően megyei szinten a vizsgált időszak elejétől, valamint a 2008-as válság után, 2010-tôl mérsékelt árbevétel és éves átlag alkalmazotti létszám növekedés mutatkozott, de 2014-től exponenciális fejlődésnek indultak a vizsgált adatok, azonban desztináció típusonként eltérő tendenciákkal találkozhatunk mindkét szolgáltató vállalat kategória tekintetében. A szállásszolgáltatók esetén főleg a legtöbb vállalattal rendelkezô városi-, illetve gyógy- és fürdő turizmusra alkalmas területek emelkedtek ki, a vendéglátással tevékenykedők esetén pedig Nagyvárad. A 2020as pandémia és a következtében behozott korlátozások miatt a 2017-es szint alá csökkentek az értékek, bár desztináció típusonként vizsgálva szintén láthatóan eltérő tendenciák mutatkoztak. A szálláshelyek tekintetében a gyógy- és fürdő turizmusra alkalmas területeket érintette legnagyobb mértékben, a vendéglátás esetén pedig a megyeszékhelyet főleg, ami a magas vállalati számnak is köszönhető. Az átlagos évi alkalmazottszámot tekintve 2014-től jelentkezett a nagyobb növekedés, a 2008-as válságot követően is mérsékelt növekedés mutatkozott, míg 2020-ban megyei szinten 8,27\%-os létszám csökkenés volt mérhető a szállásszolgáltatók és 15,65\%-os létszámcsökkenés a vendéglátás esetén.

Nagyvárad minden esetben kiemelkedik a vállaltok számával és az árbevételek, illetve alkalmazottak számát tekintve, azonban a szálláshelyek esetén Váradszentmárton önkormányzat, Félix- és Püspökfürdővel, úgy az árbevételek, mint az átlagos évi alkalmazotti létszámban kétszeres értékeket mutat. Mindenképp kiemelhető a megyeszékhely, illetve a metropolitán övezet centrum jellege megyei viszonylatban, perifériaként pedig a szálláshelyek esetén egyrészt a megye észak-keleti és déli határvonala, illetve belső perifériaként a hegyvidék és alföld közötti átmeneti terület, mely épp a megye közepén elhelyezkedő törésvonalként értelmezhető a turisztikai szolgáltatók területi fejlettségét és súlyát figyelembe véve. A vendéglátó-egységek tekintetében a falusi desztináció típusba eső önkormányzatok jelentek meg legnagyobb számban, melyeken nem regisztráltak az ágazatnak megfelelő vállalatot, viszont nem alkotnak összefüggő térségeket, legfeljebb két-két csoportban, bár megfigyelhető egy, a megye közepét észak-dél irányban átszelő vonal. 
További kutatások szükségesek a területi egyenlőtlenségek felmérésre, viszont a jelen tanulmány alapul szolgál a jövőbeli primer kutatások elvégzéséhez a szállás- és vendéglátói szolgáltatók befektetési irányvonalainak felmérésében, illetve a területi turizmusfejlesztés célterületeinek és a vállalkozói szféra mûködési területeinek összevetésében és elemzésére.

\section{Köszönetnyilvánítás}

Jelen publikáció/kutatás az Innovációs És Technológiai Minisztérium ÚNKP-20-3-II Kódszámú Új Nemzeti Kiválóság Programjának a Nemzeti Kutatási, Fejlesztési És Innovációs Alapból Finanszírozott Szakmai Támogatásával Készült.

\section{Hivatkozott források}

[1.] Bakk M.-Süli-Zakar I.-Szilágyi F. (2019): Partium. Borders, Ethnic Groups and Territorial Development. Budapest: Károli Gáspár University of the Reformed Church in Hungary, Faculty of Low, Budapest, pp. 254-256.

[2.] Bujdosó, Z. (2016): A turizmus és a területfejlesztés kapcsolatrendszere Magyarországon In: Kókai, S (szerk.) A változó világ XXI. sqázadi kibivásai: tanulmánykötet Prof. Dr. Hanusz. Áppád egyetemi tanár 70. születésnapja tiszteletére Nyíregyháza, Magyarország: Nyíregyházi Egyetem Turizmus és Földrajztudományi Intézet (2016) pp. 63-76.

[3.] Continental (Continental Forum Oradea) (2020): Hotel Continental Forum Oradea. Letöltés dátuma: $2020 . \quad 10 . \quad 5 . \quad$ forrás: https://continental-forumoradea.continentalhotels.ro/en/accommodation-oradea\#descriere-standard-room

[4.] Cooper, C. (2021): Essentials of tourism. Third Edition. London: SAGE Publications Ltd, pp. 4748. ISBN13 9781526494474

[5.] Dávid L.-Jancsik A.-Rátz T. (2007): Turiştikai eróforrások - a termésæeti és kulturális eróforrások turisztikeai hasznositása. 2. javitott kiadás. Gyöngyös: Globális BSc az üzleti alapképzésben, pp. 67-69, 83-86.

[6.] Dwyner, L.-Forsyth, P.-Dwyer, W. (2020): Tourism Economics and Policy. 2nd Edition. Bristol: Channel View Publications, pp. 293-294, 328-330. DOI: 10.21832/DWYER7314

[7.] Eurostat (2021): LOCAL ADMINISTRATIVE UNITS. Letöltés dátuma: 2021. 05 5. forrás: https://ec.europa.eu/eurostat/web/nuts/local-administrative-units

[8.] Horváth A. (2013): Turiz̨musfejlesztés székeelyföldön. Kolozsvár: Nemzeti Kisebbségkutató Intézet, pp. 121-123.

[9.] Hotel Muncel (2020): Sind Tour Trading Hotel Muncel. Letöltés dátuma: 2020. 10. 20. forrás: https://www.sindtour.ro/muncel.html

[10.] Hotel Padiș (2020): Complexul Padis - Baza De Tratament - Baile Felix. Letöltés dátuma: 2020. 10. 20. forrás: https://www.hotelpadis.ro/receptie

[11.] INSSE (Institutul Naţional de Statistică) (2021): Turism B19. Letöltés dátuma: 2021. 06. 10. forrás: http://statistici.insse.ro:8077/tempo-online/\#/pages/tables/insse-table

[12.] Irimiás A.-Jászberényi M.-Michalkó G. (2019): A turisztikai termék innovatív fejlesz̨tése. Budapest: Akadémiai Kiadó, DOI: 10.1556/9789634544081. Letöltés dátuma: 2021.03.23. forrás: https://mersz.hu/hivatkozas/m580turtei_10_p1\#m580turtei_10_p1 
[13.] KSH (Központi Statisztikai Hivatal) (2021): Osztályozások - Gazdasági tevékenységek egységes ágazati osztályozási rendszere (TEAOR'08). Letöltés dátuma: 2021. 03. 10. forrás: https://www.ksh.hu/teaor_menu

[14.] Lengyel M. (2004): A turiz̧mus általános elmélete. Budapest: Heller Farkas Gazdasági és Turisztikai Szolgáltatások Főiskolája, pp. 157, 159-168.

[15.] Lickorish, J.L.-Jenkins, G.L. (1997): An Introduction to Tourism, Oxford: ButterworthHeinemann, pp. 10-11.

[16.] Listafirme (Lista Firmelor Din România) (2021): 55+56-os tevékenység kódú vállalatok Bihar megyére. Letöltés dátuma: 2021. 06. 30. forrás: https://www.listafirme.ro/

[17.] ListaFirmeRomania (Lista Firme Romania) (2021): Baze de date. Letöltés dátuma: 2021. 06. 30. forrás: https://www.lista-firme-romania.ro/ro/\#search

[18.] Michalkó G. (2007a): A turizmus elméleti alapjai. Székesfehérvár: Kodolányi János Főiskola, pp. 94-106.

[19.] Michalkó G. (2007b): Magyarország modern turižmusföldrajza. Budapest-Pécs: Dialóg Campus Kiadó, pp. 213-231.

[20.] Risco (2021): Datele tuturor firmelor din România. Letöltés dátuma: 2021. 06. 30. forrás? https://www.risco.ro/

[21.] Romániai Pénzügyminisztérium (2021): Agenți economici și instituţii publice. Letöltés dátuma: 2021. 06. 30. forrás: https://mfinante.gov.ro/domenii/informatii-contribuabili/persoanejuridice/info-pj-selectie-dupa-cui

[22.] Szerző nélkül (2021): 142/2008-as Sürgösségi Kormányrendelet. ORDONANŢĂ DE URGENȚ̆ nr. 142 din 28 octombrie 2008. Letöltés dátuma: 2021. 06. 05. forrás: http://legislatie.just.ro/Public/DetaliiDocumentAfis/99417

[23.] Szerző nélkül (2021): 916/2018 Határozat. HOTĂRÂRE nr. 916 din 15 noiembrie 2018. Letöltés dátuma: 2021. 06. 05. forrás: http://legislatie.just.ro/Public/DetaliiDocument/207118

[24.] Tasnádi J. (2002): A turizmus rendszere. Második, bövitett kiadás. Budapest: Aula Kiadó, pp. 111120.

[25.] tbrcm (Statiunea de tratament balnear si recuperare a capacitatii de munca Baile 1 Mai) (2020): Hotel Ceres. Letöltés dátuma: 2020. 10. 20. forrás: https://www.tbrcm.ro/statiunea-detratament-balnear-baile-1-mai.php

[26.] Termene (2021): Firmele din România. Letöltés dátuma: 2021. 06. 30. forrás: https://termene.ro/

[27.] Totalfirme (Total Firme) (2021): Date Complete Despre Toate Firmele Românești. La Zi. Letöltés dátuma: 2021. 06. 30. forrás: https://www.totalfirme.ro/

\section{Szerző:}

Czuczor Krisztina

tanársegéd

Partiumi Keresztény Egyetem, Gazdaságtudományi Tanszék

czuczorkrisztina@partium.ro

A mûre a Creative Commons 4.0 standard licenc alábbi típusa vonatkozik: CC-BY-NC-ND-4.0 